\title{
Copyright and the Internet: The case of Napster
}

\author{
Gülbin Kıranoğlu ${ }^{1}$
}

\begin{abstract}
In the postindustrial world, information is not only a revolutionary phenomenon but also a valuable commodity of exchange, thereby protected by intellectual property rights, copyrights and patents. The interactive nature of the Internet, however, has complicated the notion of intellectual property leading to the debates of whether or not the Internet should be regulated on such basis. This article aims to understand the turn-of-the- $21^{\text {st }}$-century tension between the record industry and the innovative technology of Napster, regarding the question of validity of the legal concept of copyright in an age of Information Revolution. In this paper, the record industry's attack on Napster due to its development of "peer-2-peer sharing" service, as one of the earliest sample cases concerning the criminalization of the Cyberspace in relation to the issue of copyright will be examined. To achieve this, following an outline of different approaches to the concepts of information society and information revolution, I will address the fundamental question of whether the notion of intellectual property promotes or controls innovation by focusing on the lawsuit of Napster, Inc. vs. A\&M Records, Inc.
\end{abstract}

Keywords: Internet; information society; information revolution; copyright; intellectual property; postindustrial capitalism; globalization; mp3; peer-2-peer sharing; Napster.

\section{Introduction}

The technological revolution grounded in new communication and information technology has led to the extensive movement of information across national boundaries. The Internet by providing an international web of communication for the postindustrial economy and culture makes globalization possible. Thus, the Internet should be understood as an infrastructure for gathering and disseminating information for the global postindustrial economy. It should not, however, be understood as a determinant factor for the pursuits of democracy, equality, and socio-economic development, as some optimistic theories of 'information society' tend to privilege and therefore, fail to understand the capitalist components of the information revolution. Information, as a defining feature of the emergent postindustrial culture, is not only a medium for technological revolution but also a commodity as it carries ultimate exchange value and is protected by intellectual property rights, copyrights, and patents ${ }^{2}$. As information is getting more and more commodified in current information society, the debates on the regulation of the Internet become intensified. In this paper one of the earliest sample cases concerning the regulation of the Cyberspace will be examined.

The famous and now historical Napster Inc. vs. A\&M Records, Inc. case of December 1999-February 2001 shows that the technological revolution provokes controversy just as it generates innovative forms. In the light of the lawsuit, this study will assess the social

\footnotetext{
${ }^{1}$ Ph.D., Lecturer, Kocaeli University, Faculty of Arts and Sciences, Department of Western Languages and Literatures, TURKEY, gulbin.kiranoglu@,kocaeli.edu.tr

2 The concept of copyright was introduced by Victor Hugo and was agreed to be internationally protected in the Berne Convention for the Protection of Literary and Artistic Works in 1886.
} 
composition of the Internet in causing legal issues related to the production, consumption, and exploitation of intellectual work. The lawsuit stands at the crossroads of the opportunities that the new technology creates, the limits that constrain the users to acquire the technology, and the interests of the forces of capitalism, which can be traced in their policies. The open and interactive context of the Internet was perceived to possess a threatening potential for the existing powers of capitalism who feared that their domination might break if they cannot perfectly preserve the system of ownership regarding intellectual property. In this respect, this study demonstrates the struggle of corporate capitalism for their entitlement to control and regulate the production, circulation, and distribution of information.

The advent of the Internet is much praised for its potential in empowering the previously silenced, or the so-called marginal, communities with limited accessibility and visibility. However, it should also be taken into consideration that the institutions of capitalist globalization are hardly indifferent to the open, extensive, and competitive space of the Internet communication. The commercialization of the Internet, circa 1995, an important stage of the globalization of the communications, has not only been an instrument for struggles against capitalist consumer culture but also its very own means. In this light, globalization of communications should be studied as a contested terrain for opposing motivations. In the case of the battle between the record industry and the file-sharing network, it is Napster who approached technology to its own ends by developing the software called peer-to-peer sharing while transnational music corporations resisted against a change in distribution of music and waged a war against this new model. The battle showed that file-sharing networks prompted the consumers to reevaluate the accountability of the giants of the record industry pointing out the means that popular music is being exploited through corporate interest via intellectual property laws. The record industry, in turn, aimed to enhance technological control over copyright infringement more viciously than ever. The famous Napster versus A\&M Records lawsuit best exemplifies the diverse conflicts within the contested realm of global postindustrial culture.

\section{Approaching the information revolution}

The global phenomenon of the Internet is acclaimed since it creates a room for the flow of information and freedoms of opinion and expression more generously than the old traditional media. This is due to the decentralization of communication and interactive feature of the new medium. The transnational network presents a space that is potentially open to participation globally and extensively where freedoms of opinion and expression can easily flourish. The issues of freedoms of expression and free flow of information on the Internet, nevertheless, raise legal questions and are approached variably. The liberal approach defends the premise that the content on the Internet is private property whereas the conservative approach claims that the content, on the contrary, is public and, thus, should be regulated in certain situations. The interactive feature of the Internet which allows the user to produce and consume information at the same time complicates the discussions of what should be conceptualized as public and private on the Internet. In this respect, freedoms of expression and access to information constitute universal personal rights, while the circulated information is public and requires regulation for public interest. (Timisi, 2003, pp. 197-203)

Apart from the liberal and conservative approaches to the issue of regulating the Internet, a third approach supports the self-regulation of the new medium. The Electronic Frontier Foundation (EFF) promotes the recognition of digital rights since they truly believe in the Internet's potential for paving the way for greater freedom. John Perry Barlow who is the cofounder of EFF and a lyricist to a famous rock-band Grateful Dead which was famous for its encouragement to copy and share their music among fans, does not approve the idea of policing the Internet through current copyright laws. In his "A declaration of the independence of cyberspace" Barlow addresses to the established political institutions as he defines himself a 
native of Cyberspace and states: "Your legal concepts property, expression, identity, movement, and context do not apply to us. They are all based on matter, and there is no matter here (the Internet). .... The only law that all our constituent cultures would generally recognize is the Golden Rule" (Barlow, 1996, paras. 9-10). He then accuses the government for betraying the American revolutionary spirit: "In the United States, you have today created a law, the Telecommunications Reform Act, which repudiates your own Constitution and insults the dreams of Jefferson, Washington, Mill, Madison, DeToqueville, and Brandeis. These dreams must now be born anew in us" (Barlow, 1996, para. 11). He also uses a metaphor for the relationship between information and the law on intellectual property in another article entitled "The economy of ideas: A framework for patents and copyrights in the digital age"; he claims that "the bottle was protected, not the wine" by comparing the flow of information to wine and intellectual property law to the bottle con(s)t(r)aining the wine (Barlow, 1994, para. 14).

In a slightly different vein, a professor of Law, Lawrence Lessig, in his book Code and other laws of Cyberspace (1999), advocates that computer code should not merely promote but also protect innovation and that less or limited regulation would eventually guarantee innovation. Lessig in the preface to his second edition (or in his words "Version 2.0"), from the year he published the first edition in 1999 to the publication of the second one in 2006, with a view to pointing out to the validity of his prediction and criticizing what he calls as "Internet exceptionalists", concludes that "the dominant idea [...] that cyberspace was beyond the reach of real-space regulation [....] that the Internet would remain unregulated is gone" (Lessig, 2006, p. ix). Lessig then founded Creative Commons, a non-profit organization which supports sharing of information with less commercial motivation. Lessig is concerned about the hegemony of the recording industry which leads to demands of ultimate protection of capitalist interests and constraints on the power distribution. The foundation of Creative Commons is his contribution to the solution of the problem through more realistic and legal means.

The approaches which championed the Internet for its revolutionary potential, however, have been hesitant to recognize the fact that technology is not the organizing principle of a society. The movements of open source that take technological development for granted in pursuit of democracy overlook the capitalist components of technology. From Richard Barbrook's thesis of "Hi-tech gift economy," which is a compromised form of trade and gift relations co-existing in symbiosis in Cyberspace as an advanced form of social democracy to Eric S. Raymond's opposition against the industry's 'cathedral' model with the advocacy of 'bazaar' model, these visions, however feasible they may appear, are fighting against capitalism, the powerful ideology behind the law system, which privileges omnipresent control by the capitalist classes or, in Raymond's words, the 'cathedral' (Barbrook, 2005; Raymond, 1998). Thus, it would be optimistic to celebrate the Internet solely as a weapon which can bring about democracy and freedom since global access to it was the result of its commercialization. Any project which has a potential to disrupt or transform the system may also be appropriated by the market forces just like Napster once was a multimillion dollar business venture. Napster's expectations were immediately ruined by the record industry's attack and today the case of Napster stands as a landmark controversy regarding the transformations brought about by the advent of the Internet.

\section{Problematization}

The economy of Napster, for the record industry, was destructive in terms of hurting the flowing copyright revenue. It is claimed that as of 1999, the revenue acquired by recorded music industry has started to fall whilst the number of Napster's users was increasing. To be more precise, (economists claimed that), from 1998 to 2012 North American revenue decreased by $\% 75$ and European revenue decreased by $\% 70$. Napster, on the other hand, during its initial period, was getting popular among American youth, especially among college students, 3/4 of which were using Napster "at least once a month" in 2000 (qtd. in Carter \& Rogers, 2014, p. 1). 
During the controversy, however, Napster rejected the accusations of causing decrease in the market sales and argued that its service was mostly ( $\% 84$ of all Napster's users) used for 'sampling' as part of consumer behavior before the purchase of the album. (Spitz \& Hunter, 2005 , p. 176) The recording industry, rather than taking advantage of Napster as a technological innovation which would contribute to the digital music consumption, did see it as a threat, a gesture that raises questions of acceptability of innovation. Although Napster was championed as a "'game-changing' instrument" by some, the industry went to the court, blaming Napster for copyright infringement (qtd. in Spitz \& Hunter, 2005, p. 170). Additionally, in response to disadvantageous consequences of file-sharing technology, record companies demanded to strengthen copyright laws and regulations through institutions such as the HADOPI and American SOPA and PIPA. (Aguiar \& Waldfogel, 2016, p. 1) At this point, the question of what the objective of copyright is should come to mind. The Cyberspace Law Institute authors David Johnson and David Post argue that the rationale behind the copyright law should not be about protecting securely the revenues of the industry as they focus on the positive consequences of the information revolution:

The basic justification for copyright protection is that bestowing an exclusive property right to control the reproduction and distribution of works on authors will increase the supply of such works by offering authors a financial incentive to engage in the effort required for their creation. But even in the "real world," much creative expression is entirely independent of this incentive structure, because the author's primary reward has more to do with acceptance in a community and the accumulation of reputational capital through wide dissemination than it does with the licensing and sale of individual copies of works. And that may be more generally true of authorship in Cyberspace; because authors can now, for the first time in history, deliver copies of their creations instantaneously and at virtually no cost anywhere in the world. Johnson \& Post, 1996, sec. 2)

Clearly, Johnson and Post sympathize with the global, trans-border, and interactive nature of the medium and praise the prospect of immediate distribution of intellectual work as revolutionary for the creators.

Surely, copyright law is a tool through which the global music industry maintains its position in this power relationship. Nevertheless, technological innovations have always forced the limits of established legal regulations. In the past, similarly, radio or home recording technologies challenged the industry, which caused the industry to sue the manufacturers of these technologies as well. (Spitz \& Hunter, 2005, p. 173) Today these technologies are part of consumer interest and experience although in the past they too had infuriated their respective industries. However in their article entitled "Contested codes: The social construction of Napster" Spitz and Hunter claim that Napster has pushed the boundaries further as they point out to the distinctiveness of Napster due to the uncontrollable scale of the virtual space for the industries which rely on copyright revenues:

\section{Even with a subscription fee, Napster combined the worst of all possible worlds -a "monster" as Judge Patel put it-because consumers could get unlimited, on-demand access, maintain permanent copies, and freely distribute them to friends at no cost (by e-mail or otherwise). But because of the Internet's scale, and by virtue of the fact that copying could occur at essentially zero marginal cost, and without any quality loss, Napster was also an entirely different beast. (Spitz. \& Hunter, 2005, p. 173)}

Compared to old media technologies, online information can be much more easily reached, copied, and distributed. The sharing of information, however, is harder to track since an 
intellectual work on the net does not have a physical form like CD or tape. Despite the hardships, there are some applicable statutory laws to service this mission of regulating the Internet in terms of copyright law. As early as 1995, during the same period when the Internet was commercialized, "White paper on intellectual property and the national information infrastructure" was released. This paper proposed to update the copyright law according to the changing conditions of the digital age. U.S. Congress later passed the Digital Millennium Copyright Act of 1998, based on this report ${ }^{3}$. Moreover, the No Electronic Theft Act of 1997 defined the criminal penalties for copyright infringement by electronic means. More recently, UK Prime Minister David Cameron commissioned the Hargreaves Report which urged "the development of the IP system [to be] driven as far as possible by objective evidence" whereas the report by National Research Council in the US recommended to foundation of a "robust research enterprise" to regulate the production, storage, use, access and dissemination of information (qtd. in Aguiar \& Waldfogel, 2016, p. 3).

These laws that attempted to regulate the use of intellectual property on the Internet, nevertheless, could not end the discussions. The intensification of legal acts prompted counter force of anti-copyright. Negativland, an experimental music band, is one of the supporters of anti-copyright movement and Creative Commons, as the band believes that copyright has been transformed into a tool of exploitation within the context of new global information society. Here is how the band announced their support of free use of material with "artistic intent" in their "Negativland's tenets of free appropriation":

\begin{abstract}
No matter how valid the original intent of our copyright laws may have been, they are now clearly being subverted when they are used to censor resented works, to suppress the public need to reuse and reshape information and to garner purely opportunistic incomes from any public use of previously released cultural material which is, in fact, already publicly available to everyone, the U.S. Constitution clearly shows that the original intent of copyright law was to promote a public good, not a private one. No one should be allowed to claim private control over the creative process itself. This struggle is essentially one of art against business, and ultimately about which one must make way for the other. (Negativland, n.d., para. 9)
\end{abstract}

Anti-copyright movement, which promotes chaos and anarchy in Cyberspace, aims to call attention to the fact that the notion of copyright serves only to reinforce monopoly control by emphasizing the idea that 'property is theft'.

\title{
Napster, Inc. vs. A\&M Records, Inc.
}

The novelty that the RIAA vs. Napster lawsuit created has strengthened the belief that the consumers are being exploited by the legal phenomenon of copyright, which aimed to turn any possible public use into cash. Before the lawsuit, critics and scholars were already arguing the fact that the current law on intellectual property prioritized copyright holders at the expense of artists and creators. A major cultural studies scholar and a popular music critic Simon Frith states that, "... copyright is and always has been about corporate rather than artist (or consumer) interest" (qtd. in P., 2002, para. 2). He points out to the close dependence of music recording on the economics of the industry and the protection of copyright, which he calls as

\footnotetext{
${ }^{3}$ Established within the United Nations in 1974, World Intellectual Property Organization (WIPO) is responsible for developing treaties with a view to protecting the rights of intellectual property holders. In 1994, concurrent with the foundation of World Trade Organization a multilateral agreement of Trade Related Intellectual Property Rights (TRIPs) was signed due to the insufficiency of WIPO, to solve international conflicts in standardizing the regulations regarding the intellectual property in member countries. (Yüksel, 2001, pp. 248-254).
} 
"industrialization of music" (qtd. in Jones, 1993, p. 90). Steve Jones in his article "Who fought the law?" also describes the exploitation of popular music "as an investment with global dividends" (Jones, 1993, p. 83). He remarks that:

\begin{abstract}
Copyright has less to do with author's protection and the establishment of an 'authentic' original and more to do with profit [....] Record companies have long recognized the importance of copyright as a means of producing income, and the $\mathrm{RIA} A$ is very actively engaged in international lobbying to bring copyright legislation to as favorable a position for copyright-holders as possible. (Jones, 1993, p. 91)
\end{abstract}

Reebee Garofalo also points out the legal activities of the record industry emphasizing the fact that in the 1990s "corporate capital has expanded its hold over intellectual property rights in at least three critical areas: extending the term of copyright, narrowing the arena for fair use, and creating brand-new intellectual property rights" (Garofalo, 1999, p. 348). Paul Rutten also puts it very clearly that, "the music industry's economic future lies more in the exploitation of copyright and performing rights than solely in the selling of sound carriers" (Rutten, 1993, p. 43). Therefore it was no surprise that the record industry as represented by the RIAA would fight at their best not to lose control over their total domination of the market. In this aspect, it can be argued that the Internet not only made it easier to acquire free or cheaper music by expanding the users' connectivity to a worldwide population but also opened up a new space for the copyright industry to police the crisis. This clearly shows that record industry is extremely motivated to guarantee their monopoly and domination even further than the consequences of the previous court actions against radio stations and recording device manufacturers.

Although many scholars championed the Internet for having a revolutionary potential compared to traditional media, Clayton Christensen, in his The innovators dilemma which was published as early as 1997, remarked that innovations might get "disruptive" and lead to the dismantling of the established structure of an industry. (qtd. in Spitz \& Hunter, 2005, p. 169) This approach prompted Napsters' case to be evaluated "as an object lesson in how Web-based, information and communication technology can challenge long and widely held notions about economic competition and industrial organization" (Spitz \& Hunter, 2005, p. 170). Although today Napster is defined as "strings of code that forever changed the relationship between technology and music", it is difficult to point out to a destruction of the record industry (qtd. in Carter \& Rogers, 2014, p. 1). Thus Napster does not only embody the wake or the revolutionary development which helped consumers to find an opportunity to free themselves from paying large fees for listening to music, but also stands as a scapegoat which was blamed for illegal copyright infringement and destroying the media industries flowing revenues. Nevertheless, as argued by Carter and Rogers, Napster's technological innovation was in fact not new at all. IRC and the Usenet were already in use by peers for such purposes ${ }^{4}$. Napster just changed the scale which showed that it was becoming "the norm, not the exception, for the flow of information" (qtd. in Carter \& Rogers, 2014, p. 3). Scholars like Spitz and Hunter, therefore, refuse to acknowledge Napster as the sole actor in transforming the relations between the Internet users and the music industry but point out that it is the embodiment of the shift to digitization (Carter \& Rogers, 2014, p. 3).

Today it is very clear that due to Napster's groundbreaking technology which paved the way for a move towards digitization, the production and distribution costs have also dramatically decreased. Record industry refused to see the positive effects and innovative potential of filesharing technology and attacked back on the grounds of copyright violation. On the other hand, with the advent of peer-to-peer model which made possible the low cost of entry and the facility

\footnotetext{
4 Napster's service facilitated faster downloading of the mp3s. Its central directory connected the users with others who had the song they identified and wanted. Files were then passed in a form called 'peer-to-peer' sharing.
} 
to communicate with an enormous market of potential consumers, the idea that there was increasingly little need for record labels was brought forth. This explains why record industry publicly announced their intimidation from the Internet, especially from peer-to-peer sharing. However, the real threat was the fact that just a handful companies dominated the music industry, largely controlling distribution and marketing channels. As the consequence of the neoliberal policies of the globally expanding media, very few major players, the big 6 of BMG, CBS, EMI, MCA, PolyGram, WEA controlled distribution and marketing channels, making it an uneven playing field for smaller labels and unsigned artists. Furthermore, the global media industry were avoiding the pain of adopting different commercial models that would displace some of their existing business and instead they were aiming to promote the belief that the Internet ought not to be exempt from their policies for protecting their rights in public use.

Napster had put its finger on precisely what online music consumers wanted but what record industry guarded against. In 2000 when Fred Goodman, from the music magazine Rolling Stone interviewed the music industry professionals about Napster's rise, most of the interviewees expressed their surprise. Goodman in his magazine article concluded at the time that Napster had urged war against the music tycoons (qtd. in Carter \& Rogers, 2014, p. 1). Napster immediately became an emblem of the hope for the end of the industry's monopoly. The inspiring story of Napster as conceived in the head of a teenager as an idea that would become global network's groundbreaking innovative technology of file-sharing software not only enabling users to share music but also inspiring other softwares was circulated. This was not enjoyed long when the record industry reached violently to Napster within couple of months. RIAA claimed that the software that Napster developed was a tool to pirate digital music. RIAA soon sued Napster, claiming the music-sharing network encouraged copyright infringement by allowing people to swap songs free. Record industry also claimed that Napster harmed the industry by slowing CD sales. Napster claimed the otherwise by pointing out to the financial advantages that Napster created for the industry as the service was assessed as an convenient instrument for viral marketing, by presenting the consumers sample songs from the album. Additionally, Napster even proposed that the company would agree to be imposed a licensing agreement of $\$ 1$ billion over 5 years (Spitz \& Hunter, 2005, pp. 176, 179).

In the court, Napster defended itself heavily on the grounds of naivety and on the basis of Section 512 of the DMCA which was supposed to protect Napster. The music industry tried to discredit that image of innocence and inexperience ${ }^{5}$. RIAA president and CEO, Hillary Rosen, objected: "This is a company that is building a business. [....] This isn't, you know, just a sweet young guy that's looking for some fun in his college dorm room. They are building a business by facilitating the stealing of artists' music" ("Facing the music," 2000). Metallica manager Cliff Bernstein also criticized Napster's claims of innocence: "Napster never came to an artist and said, we're starting a company to offer this service" (Carter \& Rogers, 2014, p. 1). The President of Time Warner, Richard Parsons further claimed that Napster would cause an obstacle to progress and a threat to all the gains: "If we fail to protect and preserve our intellectual property system, the culture will atrophy ... Worst-case scenario: The country will end up in a sort of cultural Dark Ages" (qtd. in Spitz \& Hunter, 2005, p. 176). The court found Napster guilty of copyright infringement, making the case of Napster the tragic result of attempting to take advantage of a loophole in the law. Although the suit eventually led to the end of Napster's free peer-2-peer service ${ }^{6}$, other MP3 file-sharing websites such as Gnutella, Aimster, Kazaa, Napigator,

\footnotetext{
5 The claims of innocence and inexperience are related to the social construction of Napster. Whilst Napster was initially presented as a creation of a whizkid, eventually it became "a symbol for pathologizing and criminalizing kids' use of technology", as a result of the media rhetoric which stigmatized computer-savvy teenagers into criminals "armed with computers" (Spitz \& Hunter, 2005, pp. 174-175). Also see Carter and Rogers for the critical implications of rendering a legend out of the creation of Napster. (Carter \& Rogers, 2014)

${ }^{6}$ Napster was bought after its bankruptcy by Roxio in 2002. It was transformed into a music streaming service. In 2008 Best Buy acquired Napster as a means for entering the online music sector. It is now owned by Rhapsody since 2011 as
} 
AudioGalaxy, Scour and several others that utilized software inspired by Napster's system followed and multiplied.

Though the ability to protect intellectual property seemed to be fraught with difficulties, the Internet companies attempted to create systems that would thwart piracy using high-tech codes similar to those that protect a customer's credit card details. In an attempt to counter the MP3 threat, the Secure Digital Music Initiative (SDMI), which was formed to facilitate copyright protection technologies to counter the piracy issues. The Napster lawsuit was far more important than a mere piracy suit. The lawsuit forced a rethinking on the issues of copyright law that had to be balanced with the prospect of technology and needs of consumers. Further discussion focused on the results of piracy in off-record economy seeing the case of Napster as a multimillion dollar business venture that failed to produce regular flow of revenue. On the other hand, the anticopyright perspective saw the event as a resistance against corporate capitalism. Max W. Thomas in his article "Napster and the future of copyright law in a digital age" states that:

\begin{abstract}
The supporters of Napster just imagined that Napster embodies the need for democratization, regulation, rules, and globalization in the interests of people and not profit. Napster came along at the crisis point, and defined for us the conflict that may, in less time than we think, force a redefinition of our long standing notions of copyright and intellectual property. For some, Napster is the David, slaying the Goliath that is the RIAA. For others, Napster is simply piracy. (Thomas, 2001)
\end{abstract}

In this light, it is obvious that the free nature and potential of the Internet present new challenges vis-a-vis the dynamics of intellectual property laws.

\title{
Towards a conclusion
}

Andrew Shapiro argues that although the Internet transformed the control of information, the technology would only serve to the interests of those with power. In his book The control revolution where he traces the new control regime through controversies and policy issues, Shapiro recommends "a balance of power for the digital age-between self-interest and public interest, the market and government, personal control and shared power" as he describes the current state of affairs (Shapiro, 1999, p. 80):

... powerful entities are trying to limit our new digitally enabled autonomy. Some
governments, for example, are restricting our access to certain content and preventing us
from taking advantage of certain technologies. Some corporations are manipulating our
information choices while creating the illusion of personal freedom. And we,
unwittingly, may be their accomplices. Seduced by the rhetoric of individual power, we
may not even realize that the old guard is still in charge. (Shapiro, 1999, p. 81)

It is not surprising that the rhetoric of intellectual property is used as a suppressive instrument for the economic wealth that can be utilized in the cycle of capital accumulation to generate more wealth, which in turn enhances a monopoly. For the powerful technologies to reinforce copyright, there are digital watermarks, click-wrap contracts, trusted systems, and other developed high technology as Shapiro noted.

James R. Beniger, who wrote a book also entitled The control revolution, claims that information society, in fact, is oriented by producing new technologies in order to overcome the crisis that capitalism faces in production, distribution, and consumption (qtd. in Geray, 2002, p. 123). This coincides with Armand Mattelart's claim that information society, with its emphasis on

an online music store. ("Napster (pay service)," n.d.) 
global networking, is in fact, reevaluation of the old doctrine of 'free flow of information' in a total economic perspective (Mattelart, 2001, p. 111). In a similar vein, Herbert Schiller, who views information revolution as the ultimate event that helps the corporate capitalism to get global, argues that "a great amount of information is withheld from the public because it is regarded and treated as proprietary by its corporate holders" opposing to the prevailing belief that new media would bring democracy (qtd. in Webster, 1995, p. 93). Indeed, intellectual property laws play a role in guaranteeing the empowerment of those who already have power. This shows that the regulation of the Internet are more likely to be driven by the marketplace interests than the belief in the Internet users' good will.

There are certainly positive aspects to information revolution, which opens up new spaces and presents new opportunities for struggles against postindustrial capitalism. The freedom of the Internet facilitates new ideas of production and new ways of content distribution. However, it should not be overlooked that copyright owners and the existing market dominators are impoverishing these new forms of creativity. In this aspect, globalization seems to perpetuate the hegemony of the political and economic powers instead of diffusing technology for opportunities to fight against domination and exploitation. It is true that Napster carried a message against the excesses of corporate capitalism. The record industry's efforts to control the market strictly were countered with the anti-copyright movements and protests of the Internet communities. However, this does not make Napster a tool for democratization or resistance. Furthermore, the lawsuit paved the way for a number of changes in the legal environment, aiming to change the Internet into a platform where it is easier for the interest groups to exercise control over innovation. By monitoring and policing the Internet via technology, copyright owners aim to gain ever-expanding control of the use of intellectual and cultural material.

\section{References}

Aguiar, L., \& Waldfogel, J. (2016). Even the losers get lucky sometimes: New products and the evolution of music quality since Napster. Information Economics and Policy, (34), 1-15.

Barbrook, R. (2005). The Hi-Tech gift economy. First Monday, (Special Issue \#3). Retrieved from http:// firstmonday.org/article/viewArticle/1517/1432

Barlow, J. P. (1994, March 1). The economy of ideas. Wired. Retrieved from http://www.wired.com/1994/03/economy-ideas/

Barlow, J. P. (1996, February 8). A declaration of the independence of Cyberspace. Electronic Frontier Foundation. Retrieved from https://www.eff.org/cyberspace-independence

Carter, D., \& Rogers, I. (2014). Fifteen years of "Utopia": Napster, Pitchfork as technologies of democratization. First Monday, 19(10), 1-17.

Facing the music. (2000, June 14). Retrieved from http://www.pbs.org/newshour/bb/entertainment-jan-june00-napster_6-14/

Garofalo, R. (1999). From music publishing to mp3: Music and industry in the twentieth century. American Music, (17), 318-353.

Geray, H. (2002). Illetişim ve teknoloji. Uluslararası birikim düzeninde yeni medya politikalar. Ankara: Ütopya Yayınevi.

Johnson, D. R., \& Post, D. (1996). Law and borders - the rise of law in Cyberspace. First Monday, 1(1), 1-17.

Jones, S. (1993). Who fought the law? The American music industry and the global popular music market. In T. Bennett, S. Frith, L. Grossberg, J. Shepherd, \& G. Turner (Eds.), Rock and popular music: politics, policies, institutions (pp. 83-95). London and NY: Routledge. 
Lessig, L. (2006). Code (Version 2.0). NY: Basic Books. Retrieved from http://codev2.cc/download+remix/Lessig-Codev2.pdf

Mattelart, A. (2001). İletişimin dünyasallaşması. İstanbul: İletişim.

Napster (pay service). (n.d.). In Wikipedia. Retrieved from https://en.wikipedia.org/wiki/Napster_(pay_service)

Negativland. (n.d.). Negativland's tenets of free appropriation. Retrieved from http://www.negativland.com/news/?page_id=10

P., A. (2002, September 13). Online exchange with Simon Frith, part 2. Retrieved April 30, 2016, from http:// rockcriticsarchives.com/interviews/simonfrith/02.html

Raymond, E. S. (1998). The cathedral and the bazaar. First Monday, 3(3). Retrieved from http:/ / firstmonday.org/article/view/578/499

Rutten, P. (1993). Popular music policy: A contested area - the Dutch experience. In T. Bennett, S. Frith, L. Grossberg, J. Shepherd, \& G. Turner (Eds.), Rock and popular music: politics, policies, institutions (pp. 37-51). London and NY: Routledge.

Shapiro, A. L. (1999). The control revolution: How the Internet is putting individuals in charge and changing the world we know. NY: Public Affairs.

Spitz, D., \& Hunter, S. D. (2005). Contested codes: The social construction of Napster. The Information Society, (21), 169-180. http://doi.org/10.1080/01972240490951890

Thomas, M. W. (2001). Napster and the future of copyright law in a digital age. The Internet Law Journal. Retrieved from http://til.com/content/ipheadline04140102.htm

Timisi, N. (2003). Yeni iletişim teknolojileri ve demokrasi. Ankara: Dost Kitabevi Yayınlanı.

Webster, F. (1995). Information and advanced capitalism. In Theories of the Information Society. London and NY: Routledge.

Yüksel, M. (2001). Küreselleșme, ulusal bukuk ve Türkiye. Ankara: Siyasal Kitabevi. 